\title{
Effect of disodium cromoglycate (Intal) on sputum protein composition
}

\author{
SANDRA HEILPER N ${ }^{1}$ and A. S. REBUCK \\ Thoracic Unit, The Royal North Shore Hospital of Sydney and Department of Medicine, \\ The University of Sydney, Sydney, Australia
}

The protein content in the sputum of nine patients with asthma was compared with that in 11 non-asthmatic patients by a method of gel electrophoresis. It was found that the albumin content was significantly higher in the sputum of the asthmatics than of the non-asthmatics $(\mathbf{P}<0.01)$. A further 11 asthmatic patients who were taking disodium cromoglycate (Intal) as part of their treatment had sputum albumin levels indistinguishable from the non-asthmatics. When patients with asthma were then studied serially, before and after disodium cromoglycate therapy, the albumin content returned to non-asthmatic levels within two days of starting treatment. It is suggested that disodium cromoglycate has a previously unrecognized action in altering sputum proteins.

Methods have now been developed for investigating the biochemical characteristics of bronchial mucus (Ryley and Brogan, 1968) as well as sputum viscosity (Cobbin, Elliott, and Rebuck, 1971) in patients with asthma and chronic lung disease.

Sputum production in asthma is markedly decreased in patients treated with disodium cromoglycate (Intal). This drug prevents asthmatic attacks attributable to precipitins (Pepys, Hargreave, Chan, and McCarthy, 1968) as well as having a steroid-sparing effect (Read and Rebuck, 1969).

Although various proteins in the sputum of patients with asthma have been studied, and compared with those of normal subjects (Newcomb and DeVald, 1969; Dennis, Hornbrook, and Ishizaka, 1964), the effect of disodium cromoglycate on protein characteristics has not been studied. The aim of this investigation was to assess the effect of the drug on sputum protein content in patients with asthma.

\section{PATIENTS AND METHODS}

Thirty-four patients were studied, all of whom were treated in the Thoracic Unit of the Royal North Shore Hospital of Sydney. We divided them into four groups according to the following clinical criteria:

GROUP A Nine patients with bronchial asthma, none of whom was using disodium cromoglycate. There

1Address for reprints : Mrs. S. Heilpern, Thoracic Unit, Royal North Shore Hospital of Sydney, St. Leonards 2065, N.S.W., Australia were five men and four women, whose ages ranged from 35 to 67 (mean 56) years.

GROUP B Nine patients with asthma who had been using disodium cromoglycate (4 capsules daily) for two or more days. This group consisted of four men and five women aged 19 to 67 (mean 35) years.

GROUP C Eleven patients with chronic cardiac or pulmonary disease, but not asthma. Six were men and five women, whose ages ranged from 27 to 62 (mean 53) years.

GROUP D These five patients, all female, had asthma, and were tested both before and after starting disodium cromoglycate therapy, so that they were able to act as their own controls. Their ages ranged from 17 to 46 (mean 34) years.

In no case was bloodstained sputum studied, and patients whose sputum showed bacteriological evidence of pathogenic infection were eliminated from the trial.

Sputum samples consisted of the total sputum pro- N duced by patients during the first four hours after waking. The samples were expectorated directly into jars containing $10 \mathrm{ml}$ tris-glycine buffer at $\mathrm{pH} \mathrm{8.3.}$

The gel fraction was separated by straining the sputum through gauze for 30 minutes. Gel was then 0 scraped from the gauze and its volume was measured. Gel viscosity was reduced with $0.075 \mathrm{M}$ cysteine in $\stackrel{\mathcal{Q}}{?}$ $1 / 15 \mathrm{M}$ phosphate buffer at $\mathrm{pH} 7 \cdot 5$, after which it 0 was incubated at $37^{\circ} \mathrm{C}$ for two hours (Havez, o Roussel, Degand, and Biserte, 1967). After dialysis $\underset{\mathbb{D}}{ }$ at $4^{\circ} \mathrm{C}$ for five to seven days, the specimen was centrifuged at $15,000 \mathrm{rev} / \mathrm{min}$ for 30 minutes, and the supernatant was used for further testing. 
TOTAL PROTEIN ESTIMATION This was performed by the method of Lowry, Rosebrough, Farr, and Randall (1951), the standards being beef serum albumin. Corrections were made for the dilution factor arising from the cysteine solution. Due to the extreme viscosity of the gel sample before reduction, initial and subsequent volumes were measured correct to $0.5 \mathrm{ml}$. No significant volume changes were noted following dialysis.

ELECTROPHORESIS This procedure was performed on $100 \mu \mathrm{l}$ aliquots of cysteine reduced, dialysed, centrifuged sputum samples, using gradipore polyacrylamide electrophoresis, as described by Margolis and Kenrich (1968), and a current of 240 volts for one and three quarter hours was applied. Such a high potential difference was chosen because of the nature of the mucin protein complexes involved (Margolis, 1971). Gradipore gradient gel slabs were used, ranging from $4 \%$ to $26 \%$ polyacrylamide in each slab.

Tris glycine buffer pH $8.3 \quad(0.05 \mathrm{M}$ tris, $0.38 \mathrm{M}$ glycine), as described by Davies (1964), was used as the buffer for electrophoresis, with the addition of $1 \%$ EDTA for finer separation.

The gel was stained for protein with $1 \%$ amido black in $7 \%$ acetic acid. Where the protein content was too low to give visible bands in the gel, the sample was concentrated by freeze drying and redissolved in a smaller volume of distilled water. No turbidity was noted in the resulting solution after reconstitution. The stained protein in the gel was scanned in a Farrand thin-layer chromatography spectrofluorometer at $600 \mathrm{~nm}$. The percentage albumin in each sample was measured by planimetry of the resulting chromatogram.

\section{RESULTS}

Electrophoresis on gradipore acrylamide gels resolved the soluble proteins in the sputum into visible bands. Albumin was always present, and the number of bands with less electrophoretic mobility than albumin varied from one to five. Visible bands with greater electrophoretic mobility than albumin varied from 0 to 4 . These variations bore no relationship to grouping of samples into asthmatics or non-asthmatics, or to whether or not patients were taking disodium cromoglycate.

There was no significant difference between the absolute protein content of sputum in the various clinical groups. However, the relative concentration of albumin in the sputum of the patients with asthma was significantly greater than in that of non-asthmatic subjects $(P<0.01$, Student's test $)$. When asthmatic patients were taking disodium cromoglycate, the mean albumin concentration in sputum was significantly less than in those patients not taking the drug $(P<0 \cdot 01)$. In five asthmatic
T A B L E

PROTEIN CONTENT OF SPUTUM IN PATIENTS WITH ASTHMA

\begin{tabular}{|c|c|c|}
\hline Patient Group & $\begin{array}{l}\text { Total Protein } \\
(\mathrm{mg} \%)^{1}\end{array}$ & Per cent Albumin \\
\hline $\begin{array}{l}\text { A (asthma) . } \\
\text { B (asthma + Intal) } \\
\text { C (non-asthmatic) } \\
\text { D (asthma before and } \\
\quad \text { after Intal) }\end{array}$ & $\begin{array}{r}412(\mathrm{SD}=162) \\
743(\mathrm{SD}=728) \\
282(\mathrm{SD}=147) \\
+116(\mathrm{SD}=59)\end{array}$ & $\begin{array}{r}29 \cdot 5(\mathrm{SD}=7 \cdot 6) \\
16 \cdot 0(\mathrm{SD}=7 \cdot 6) \\
17 \cdot 1(\mathrm{SD}=6 \cdot 4) \\
-8 \cdot 9(\mathrm{SD}=4 \cdot 1)\end{array}$ \\
\hline
\end{tabular}

SD $= \pm$ standard deviation

$1 \mathrm{mg} \%$ of drained gel fraction of sputum

patients, serial studies of sputum proteins were made over several days during which disodium cromoglycate therapy was introduced. Within two days of starting therapy, there was a significant decrease in albumin concentation $(P<0.02)$ accompanied by an increase in total protein $(P<0.02)$. These results are summarized in the Table.

\section{DISCUSSION}

This study offers clear evidence that the protein characteristics of the sputum of patients with asthma differ from those of patients with other forms of lung disease. Like Brogan, Ryley, Allen, and Hutt (1971), we have shown that this difference can be identified in the albumin concentration. In patients with asthma there is a significant increase in the relative albumin concentration in the sputum. Brogan et al. felt that the proportion of albumin in sputum sol phase high-molecularweight substances might hold promise as a criterion for distinguishing between asthma and chronic bronchitis.

Disodium cromoglycate (Intal) was tested because it was known that it had a marked clinical effect on the sputum of patients with asthma. We have found that disodium cromoglycate converts the albumin concentration in the sputum of asthmatics to levels found in non-asthmatic subjects. In estimating the percentage of albumin in the sputum of the asthmatics only small samples were available for assessing total protein as the sputum volume had been reduced following treatment with disodium cromoglycate. This extreme reduction in the volume and gel content of the sputum in these patients necessitated the use of the Lowry method of protein estimation which requires only one-tenth of the volume of prepared sputum, compared with the more widely used Biuret method.

It is unlikely that salivary contamination played a role in influencing these results. Like Ryley and Brogan (1968), we used drainage on cotton gauze 
and low-speed centrifugation to remove saliva from test substances. In addition, the sputum was always expectorated into $\mathrm{pH} \mathbf{8 . 3}$ buffer, in the belief that this would minimize digestion of sputum glycoproteins by salivary amylase, even though there is little experimental evidence that this would be the case. It could be said that the use of the buffer for collection of samples has permitted some diffusion of soluble proteins into the surrounding buffer. However, the same procedure was used for each group, and differences were significant between groups, indicating a lower percentage of albumin in the treated sputum of asthmatics taking disodium cromoglycate, compared with the treated sputum of asthmatics not taking the drug.

It could also be said that the total protein estimations and the electrophoresis performed on the treated samples were only semi-quantitative due to intrinsic proteolysis and resulting protein loss during sample preparation. However, the results of this study are based on the per cent that albumin represented of the total protein of the chromatogram. Hence absolute values were not used in comparing the groups.

It is possible that the present study has thrown further light on the mode of action of disodium cromoglycate in asthma. The drug prevents the release of chemical mediators resulting from antigen-reagin reactions (Orange and Austen, 1968), and, as might be expected, it is of considerable benefit to patients with asthma of allergic origin.

However, many patients in whom no 'allergic' origin can be identified appear to benefit from disodium cromoglycate. For example, Davies (1968) has demonstrated that the drug will prevent episodes of exercise-induced asthma, in which it is hard to imagine any allergic reaction playing a significant triggering role.

This study does not attempt to explain why disodium cromoglycate is also effective in nonallergic asthma. However, the evidence points to a previously unrecognized action of the drug, that of lowering albumin concentration in sputum to levels found in non-asthmatic patients. The signifio cance of this finding awaits further study.

This work was supported by a research grant byD Fisons Pty Ltd. The authors wish to thank Dr. W Allan Crawford, O.B.E., M.B., Ch.B., Ph.D., for enङ couragement in the conduct of this work, and Dr. $\mathrm{J} \vec{\circ}$ Margolis for helpful advice.

\section{REFERENCES}

Brogan, T. D., Ryley, H. C., Allen, L., and Hutt, H. (1971) N Relation between sputum sol phase composition ands diagnosis in chronic chest diseases. Thorax, 26, 418.

Cobbin, D. M., Elliot, F. M., and Rebuck, A. S. (1971). ThN mucolytic agent bromhexine (bisolvon) in chronic lung disease: a double-blind crossover trial. Aust. N.Z. J. Med., 1, 137.

Davies, B. J. (1964). Disc electrophoresis II. Method an $\overline{6}$ application to human serum proteins. Ann. N.Y. Acad Sci., $121,404$.

Davies, S. E. (1968). Effect of disodium cromoglycate or exercise-induced asthma. Brit. med. J., 3, 593.

Dennis, E. G., Hornbrook, M. M., and Ishizaka, K. (1964) $\overrightarrow{0}$ Serum proteins in sputum of patients with asthma. $J \mathrm{~N}$ Allergy, 35, 464.

Havez, R., Roussel, P., Degand, P., and Biserte, G. (1967) Étude des structures fibrillaires de la sécrétion bronß chique humaine. Clin. chim. Acta, 17, 281.

Lowry, O H., Rosebrough, N. J., Farr, A. L., and Randallo R. J. (1951). Protein measurement with the Folin pheno? reagent. J. biol. Chem., 193, 265.

Margolis, J. (1971). Personal communication.

and Kenrich, K. G. (1968). Polyacrylamide gel electro phoresis in a continuous molecular sieve gradient. Analyt $\bar{D}$ Biochem., 25, 347.

Newcomb, R. W., and DeVald, B. (1969). Protein con centrations in sputa from asthmatic children. J. Lá́ clin. Med., 73, 734 .

Orange, R. P., and Austen, K. F. (1968). Prospects in asthmâx therapy: disodium cromoglycate and diethylcarbamazine. New Engl. J. Med., 279, 1055.

Pepys, J., Hargreave, F. E., Chan, M., and McCarthy, D. Sß (1968). Inhibitory effects of disodium cromoglycate on allergen-inhalation tests. Lancet, 2, 134.

Read, J., and Rebuck, A. S. (1969). Steroid-sparing effect of disodium cromoglycate (Intal) in chronic asthma. Med. J. Aust., 1, 566.

Ryley, H. C., and Brogan, T. D. (1968). Variation in the composition of sputum in chronic chest diseases. Brit\} J. exp. Path., 49, 625. 